\title{
HUBUNGAN ANTARA KEMAMPUAN BERPIKIR KRITIS ASPEK MENGANALISIS DAN ASPEK MENARIK KESIMPULAN TERHADAP HASIL BELAJAR IPA SISWA KELAS V SDN SEKECAMATAN KLIRONG TAHUN AJARAN 2020/2021
}

\author{
Syifa Lailatul Mutmainnah ${ }^{1}$, Suhartono², Kartika Chrysti Suryandari ${ }^{3}$
}

Universitas Sebelas Maret

syifalaila2907@gmail.com

\section{Article History}

accepted $1 / 11 / 2021$

\begin{abstract}
21st century skills push students to have critical thinking skills. Those skills are developed in learning process so that the students will obtain the desired learning outcomes. The study aimed to analyze the positive correlation between: (1) critical thinking skills in the aspect of analyzing and natural science learning outcomes, (2) critical thinking skills in the aspect of drawing conclusion and natural science learning outcomes, and (3) critical thinking skills in the aspect of analyzing and drawing conclusion on natural science learning outcomes. The research was correlational quantitative method. The results showed that (1) there was positive correlation between critical thinking skills in the aspect of analyzing and natural science learning outcomes. The Sig. was 0.000 and $r$ arithmetic $t$ was 0.820 ; (2) there was positive correlation between critical thinking skills in the aspect of drawing conclusion and natural science learning outcomes; The Sig. was 0.000 and $r$ arithmetic was 0.816; (3) there was positive correlation between critical thinking skills in the aspect of analyzing and drawing conclusion on natural science learning outcomes. The Sig. was 0.000 and $r$ arithmetic was 0.885
\end{abstract}

Keywords: critical thinking, analyzing, drawing conclusions, learning outcomes

\begin{abstract}
Abstrak
Keterampilan abad ke-21 menekankan siswa memiliki kemampuan berpikir kritis.Kemampuan berpikir kritis siswa dikembangkan dalam proses pembelajaran sehingga akan memperoleh hasil belajar yang diinginkan.Penelitian ini bertujuan untuk menganalisis hubungan postif (1) kemampuan berpikir kritis aspek menganalisis dengan hasil belajar IPA, (2) kemampuan berpikir kritis aspek menarik kesimpulan dengan hasil belajar IPA, dan (3) kemampuan berpikir kritis aspek menganalisis dan menarik kesimpulan dengan hasil belajar IPA. Penelitian ini merupakan penelitian kuantitatif dengan metode penelitian korelasi. Hasil penelitian menunjukkan bahwa(1)kemampuan berpikir kritis aspek menganalisis memiliki korelasi positif terhadap hasil belajar IPA dengan nilai Sig. 0,000 dan nilai $r$ hitung 0,820; (2) kemampuan berpikir kritis aspek menarik kesimpulan memiliki korelasi positif terhadap hasil belajar IPA dengan nilai Sig. 0,000 dan nilai $r$ hitung 0,816; dan (3) kemampuan berpikir kritis aspek menganalisis dan menarik kesimpulan memiliki korelasi positif terhadap hasil belajar IPA dengan nilai Sig. 0,000 dan nilai $r$ hitung 0,885 .
\end{abstract}

Kata kunci: Berpikir kritis, menganalisis,menarik kesimpulan, hasil belajar 


\section{PENDAHULUAN}

Perkembangan dunia pendidikan pada abad ke-21 menekankan pada aspek pendidikan yang bermakna, dimana fokus pengembangan melalui cara dan solusi menyelesaikan permasalahan yang terjadi dalam kehidupan setiap harinya. Pendidik pada abad ke-21 dituntut untuk menjadi pendidik yang profesional tidak hanya bisa menjelaskan tetapi dapat menjadi fasilitator perubahan kualitas pembelajaran di sekolah. Keterampilan abad ke-21 yang sering disebut dengan 4C keterampilan ini yang harus dikembangan oleh pendidik dan harus dimiliki oleh peserta didik yaitu Communication, Collaborative, Critical Thinking, dan Creativity. Kemampuan ini juga selaras dengan desain kurikulum 2013 yang ingin dicapai dengan tidak hanya menitik beratkan pada pengembangan kemampuan hard skill tetapi pengembangan soft skill sehingga dapat diimplemantasikan dalam kehidupan setiap harinya.

Memecahkan permasalahan dalam kehidupan sehari-hari dapat dilakukan salah satunya dengan kemampuan berpikir kritis pada peserta didik. Kemampuan berpikir kritis adalah kesanggupan pemikiran secara rasional dan logis dalam memutuskan penyelesain masalah menggunakan proses ilmiah dengan menganalisis, mensintesis, memahami masalah dan penyelesaianya, menarik kesimpulan serta mengevaluasi (Prameswari, Suharno, \& Sarwanto, 2018). Kemampuan berpikir kritis sebagai pegangan bagi peserta didik dalam mencapai tingkatan belajar sepanjang hayat dan menghadapi permasalahan masa mendatang. Kemampuan berpikir kritis menurut Facione (2011) meliputi: (1) interpretasi/interpretation; (2) analisis/analysis; (3) evaluasi/evaluation (4) kesimpulan/inference; (5) penjelasan/explanation; (6) penguatan diri/self-regulation.

Kemampuan berpikir kritis dapat dilakukan pada semua muatan pelajaran, salah satunya yaitu muatan pelajaran IPA. Wenno (Makhrus, dkk., 2018) mengatakan bahwa mempelajari IPA bukan hanya mempelajari wujud pengetahuan deklaratif baik konsep, hukum, prinsip maupun fakta tetapi mempelajar IPA juga belajar proses mendapatkan laporan secara sains yang akan meningkatkan kemampuan berpikir kritis, memiliki nalar yang logis serta dapat memecahkan permasalahan dengan kreatif. Pada pembelajaran IPA siswa melakukan penyelidikan di alam sekitar untuk menumbuhkan cara berpikir rasional dan ilmiah yang sesuai cara kerja ilmiah. Kerja ilmiah yaitu cara menemukan konsep sains atau biasa disebut keterampilan proses sains yakni kemahiran bernalar, berpikir kritis, dan bertindak dalam menyelidiki konsep sains yang bermanfaat dalam menyelesaikan permasalahan (Nugraha, Suyitno, \& Susilaningsih, 2017).

Kemampuan berpikir kritis pada pelajaran IPA dalam melakukan proses sains sebaiknya dilatih sejak pendidikan seperti: interprestasi, menganalisis, mengevaluasi, menarik kesimpulan, menjelaskan dan penguatan diri, hal ini karena sebagai pondasi dan bermanfaat untuk tingkatan pendidikan selanjutnya. Dengan hal ini juga selaras dengan tujuan kurikulum 2013 dalam standar isi muatan IPA kelas V dan VI SD yang tercantum pada Peraturan Menteri Pendidikan dan Kebudayaan Nomor 64 Tahun 2013 diketahui bahwa dalam pelaksanaan proses pembelajaran IPA diharapkan peserta didik memperlihatkan kemampuan berpikir kritis, logis, rasional, analalisi, bertanggung jawab, membedakan fakta, dan dapat menarik kesimpulan yang kemudian dilaporkan dan dipresentasikan dengan menggunakan proses sains dan sikap ilmiah.

Kenyataannya di lapangan kemampuan berpikir kritis peserta didik SD masih belum diberdayakan, hal ini dapat dilihat berdasarkan hasil wawancara awal yang dilakukan pada guru kelas V SDN 3 Kedungwinangun, SDN Wotbuwono, dan SDN 1 Tambakagung tentang kemampuan berpikir kritis siswa kelas $V$ SDN pada pelajaran IPA diperoleh masih terdapat ketidak sesuaian dalam mengidentiifikasi hubungan antara konsep organ pencernaan pada manusia dengan fungsinya. Selain itu, proses pembelajaran masih mengalami kesulitan dengan menggunakan pembelajaran berbabisis kemampuan berpikir kritis sehingga lebih dominan menggunakan pembelajaran berpusat pada guru yang mengakibatkan siswa masih kesulitan dalam 
kemampuan berpikir kritis menganalisis dan menarik kesimpulan pada sebuah soal cerita, gambar atau bagan. Ketika pembelajaran di kelas kemampuan berpikir kritis membedakan peredaran darah besar dan peredaran kecil siswa belum berkembang. Dalam kegiatan diskusi siswa membuat alternatif lain dalam menghadapi permasalahan organ pencernaan belum sesuai. Ketidakbiasaan kemampuan berpikir kritis berdampak pada kemampuan pemahaman belajar IPA siswa kelas V SD hal ini terlihat pada nilai PTS siswa yang belum mencapai KKM.

Facione (Pratiwi, Mirza, \& Nursangaji, 2015).mengatakan seseorang yang memiliki kemampuan berpikir kritis tidak diharuskan memiliki semua aspek berpikir kritis sebagai kemampuan kognitif, sehingga dalam melihat peserta didik memiliki kemampuan berpikir kritis dapat difokuskan pada satu atau beberapa aspek berpikir kritis yang akan diujikan. Pada aspek analisis, evaluasi dan kesimpulan sebagai pusat berpikir kritis. Berdasarkan hasil observasi awal, peneliti akan mengkaji dua aspek yaitu menganalisis dan menarik kesimpulan. Aspek menganalisis yaitu siswa mampu menghubungkan antara informasi dan konsep. Aspek menarik kesimpulan yaitu siswa dapat membuat suatu kesimpulan dalam pemecahan masalah.

Penguasaan terhadap keterampilan berpikir kritis pada proses sains dapat dilihat pada keberhasilan hasil belajar IPA. Siswa yang memiliki keterampilan berpikir kritis yang baik akan terlatih untuk mengoptimalkan kemampuan berpikir tingkat tinggi sehingga berdampak pada peningkatan pencapaian belajar siswa, terutama pada aspek kognitif (Huda \& Rahman, 2020). Namun, kenyataan dilapangan justru menujukan hasil pelajaran IPA perlu memperoleh perhatian yang lebih, hal ini ditunjukan dari Hasil studi Programme for International Student Assessment (PISA, 2018) telah dipublis pada hari Selasa, 3 Desember 2019 dalam kategori kinerja sains yakni mengalami penurunan dari laporan PISA 2015, dari nilai kenerja sains yang awalnya 403 menurun menjadi 396 diperingkat 9 dari bawah dari 71 negara (Tohir, 2019). Pendapat tersebut sejalan dengan oleh hasil belajar IPA siswa kelas V di SDN 3 Kedungwinangun dengan jumlah 22 siswa, berdasarkan perolehan PTS pada muatan IPA diketahui sebesar $31,81 \%$ siswa belum tuntas untuk tema 1 dan sebesar $68,18 \%$ siswa belum tuntas untuk tema 2 dari KKM yaitu 70. Kemudian SDN Wotbuwono dengan berjumlah 28 siswa, dengan nilai rata-rata 58,03 hanya 10 anak yang nilainya di atas 70 atau sebesar $36 \%$, sedangkan 18 anak lainnya masih dibawah nilai KKM atau sebesar 64\%. Sedangkan pada SDN 1 Tambakagung yang berjumlah 26 siswa pada muatan IPA ditehui sebesar $38,46 \%$ siswa belum tutas dengan KKM yaitu 70. Dari pemaparan tersebut menunjukan bahwa hasil belajar IPA memiliki korelasi dengan kemampuan berpikir kritis.

Penelitian sebelumnya yang memperkuat yakni yang dilakukan Yuono (2019) menunjukkan kemampuan berpikir kritis siswa memiliki hubungan yang signifikan terhadap hasil belajar Bahasa Indonesia siswa kelas V SDN 2 Mentro Utara dengan nilai $R 0,974$ (hubungan sangat kuat), nilai koefisien determinasi $\left(R^{2}\right)$ sebesar 0,949 . Dengan hal ini, kemampuan berpikir kritis memiliki hubungan yang positif dengan hasil belajar Bahasa Indonesia. Hal ini diperkuat dengan penelitian yang dilakukan Huda dan Rahman (2020: 46) dengan hasil penelitian terdapat hubungan yang signifikan antara kemampuan berpikir kritis terhadap pencapaian hasil siswa sekolah dasar, yang membuktikan tingkat kemampuan kritis sejalan dengan tingkat hasil belajar siswa sekolah dasar. Namun, sebaliknya semakin rendah kemampuan berpikir kritis maka semakin rendah pula hasil belajar siswa sekolah dasar.

Berpijak dari penjelasan tersebut tujuan penelitian ini yaitu: (1)menganalisis adanya hubungan positif antara kemampuan berpikir kritis aspek menganalisis dengan hasil belajar IPA;(2)menganalisis adanya hubungan positif antara kemampuan berpikir kritis aspek menarik kesimpulan dengan hasil belajar IPA; (3)menganalisis adanya hubungan positif antara kemampuan berpikir kritis aspek menganalisis dan menarik kesimpulan terhadap hasil belajar IPA siswa kelas V SD Negeri se-Kecamatan Klirong tahun ajaran 2020/2021. 


\section{METODE}

Penelitian ini yang merupakan penelitian kuantitatif dengan metode penelitian korelasi. Populasi penelitin ini siswa kelas V SDN se-Kecamatan Klirong tahun ajaran 2020/2021 yang berjumlah 847 siswa dari 32 SDN dengan sampel sebanyak 272 siswa dan sampel yang diperoleh sebanyak 283 siswa di sebelas SDN di Kecamatan Klirong tahun ajaran 2020/2021. Teknik sampling yang digunakan yaitu cluster random sampling.

Teknik pengumpulan data pada penelitian ini menggunakan tes uraian berfungsi untuk proses pengambilan data variabel kemampuan berpikir kritis. Variabel hasil belajar IPA diukur dengan menggunakan teknik tes pilihan ganda. Uji validitas data dan reliabilitas menggunakan rumus Alfa Cronbach. Uji prasyarat data penelitian ini yaitu uji normalitas Kolmogorov-Smirnov, uji linieritas sederhana, dan uji multikolinieritas data. Setelah data memenuhi prasyarat yang ditentukan, data akan dianalisis menggunkan analisis korelasi sederhana dan berganda. Uji hipotesis 1 dan 2 menggunakan uji korelasi sederhana dan uji hipotesis 3 menggunakan uji korelasi berganda. Setelah itu dilakukan perhitungan koefisien determinasinya.

Indikator variabel kemampuan berpikir kritis difokuskan pada aspek menganalisis dan menarik kesimpulan. Indikator berpikir kritis aspek menganalisis memiliki subindikator meliputi: mengidentifikasi hubungan antara konsep dengan permasalahan, dan menganalisis penyelesaian permasalahan. Indikator berpikir kritis aspek menarik kesimpulan subindikator meliputi: membedakan fakta permasalahan, membuat alternatif penyelesaian lain dan menarik kesimpulan dari apa yang diketahui. Indikator variabel hasil belajar IPA meliputi aspek mengingat(C1), memahami(C2), menerapkan(C3), menganalisis(C4), mengevaluasi(C5), dan menciptakan(C6).

\section{HASIL DAN PEMBAHASAN}

Sebelum data dianalisis, peneliti melakukan uji validitas dan riliabilitas. Validitas soal tes uraian Kemampuan berpikir kitis sebanyak 10 soal sedangkan validitas tes pilihan ganda hasil belajar IPA sebanyak 41 soal. Reliabilitas diperoleh rumus Alpha Cronbach dengan hasil berpikir kritis sebesar 0,866 dan hasil belajar IPA sebesar 0,908 sehingga diperoleh koefisien reliabilitas yang sangat tinggi pada instrumen. Data dianalisis dengan bantuan aplikasi SPSS versi 21.

Data deskripsi pada kemampuan berpikir kritis dan hasil belajar IPA secara berurutan diperoleh yaitu: (1) mean skor yang diperoleh yaitu 60,09 dan 62,16; dengan standar eror mean yaitu 0,800 dan 0,951 (2) median sebesar 59,89 dan 63,24. (3) modus sebesar 56 dan 63; (3) Std. Deviation (simpangan baku) yaitu 13,455 dan 16,00. (4) Skewness sebesar -0,159 dan -0,131dengan standar erornya yaitu -0,145, (5) Kurtosis sebesar 0,275 dan -0,379 dengan 0,289, (6) range (kemiringan) sebesar 74 dan 73, (7) nilai minimum sebesar 74 dan 73, (8) nilai minimum sebesar 20 dan 22,(9) nilai maksimum sebesar 94 dan 95, dan (10) sum pada penelitian ini dengan jumlah data 17.006 skor dan 17.590 skor.

Data penelitian dilakukan prasyarat analisis data terlebih dahulu menggunakan uji nrmalitas, uji linieritas dan uji multikololinieritas. Dalam penelitian ini, uji normalitas dilakukan dengan uji parametrik Kolmogorov-Smirnov (K.S). Nilai normalitas tes uraian kemampuan berpikir kritis sebesar 0,361 sehingga dapat diketahui nilai signifikansi $>\alpha$ $(0,361>0,05)$ maka Ho diterima. Jadi dapat dismpulkan bahwa data tes kemampuan berpikir kritis berdistribusi normal.Data tes hasil belajar IPA sebesar 0,374 sehingga dapat diketahui nilai signifikansi $>\alpha(0,374>0,05)$ maka Ho diterima. Jadi dapat dismpulkan bahwa data tes hasil belajar IPA berdistribusi normal

Uji linieritas diketahui nilai Sig. Deviation From Linearity untuk hasil belajar IPA dan kemampuan berpikir kritis siswa kelas V SDN sebesar 0,186. Pada data tersebut Sig. > 
$\alpha(0,186>0,005)$ maka Ho diterima. Jadi dapat disimpulkan bahwa data hasil belajar IPA dan kemampuan berpikir kritis siswa kelas $V$ SDN memiliki hubungan yang linear.

Sedangkan hasil uji multikolinieritas diketahui nilai tolerance yaitu 0,500 dan nilai VIF yaitu 2,000. Hal itu berarti nilai tolerance $>0,10$ dan nilai VIF $<10,0$ maka Ho diterima. Jadi dapat disimpulkan bahwa tidak terjadi multikolinieritas antar variabel bebas pada penelitian ini dan analisis dapat dilanjutkan.

Tabel 1. Tabel Hasil Uji Kemampuan Berpikir Aspek Menganalisis dan Menarik Kesimpulan dan Hasil Belajar IPA

\begin{tabular}{lccc}
\hline \multicolumn{1}{c}{ Variabel } & R hitung & Sig & $\begin{array}{c}\text { KP } \\
(\%)\end{array}$ \\
\hline $\begin{array}{l}\text { Berpikir kritis aspek menganalisis terhadap hasil } \\
\text { belajar IPA }\end{array}$ & 0,820 & 0,000 & 67.2 \\
\hline $\begin{array}{l}\text { Berpikir kritis aspek menarik kesimpulan terhadap } \\
\text { hasil belajar IPA }\end{array}$ & 0,816 & 0,000 & 66.5 \\
\hline $\begin{array}{l}\text { Berpikir kritis aspek menganalisis dan aspek } \\
\text { menarik kesimpulan terhadap hasil belajar IPA }\end{array}$ & 0,885 & 0,000 & 78.4 \\
\hline
\end{tabular}

Analisis hipotesis pertama menggunakan uji korelasi sederhana yaitu nilai signifikansi (2 -tailed) $0,000<0,05$ berarti $\mathrm{H}_{0}$ ditolak, sehingga ada hubungan positif antara berpikir kritis aspek menganalisis dan hasil belajar IPA. Sedangkan koefisien korelasi $r$ ihitung $=0,820$, sedangkan $r$ tabel $(d f=281)$ yaitu 0,116 . Maka nilai $r$ hitung $(0,820)>r$ tabel $(0,116)$ yang berarti memiliki hubungan sangat kuat antara kemampuan berpikir kritis aspek menganalisis dan hasil belajar IPA siswa kelas V SDN seKecamatan Klirong tahun ajaran 2020/2021. Sedangkan, nilai koefisien determinasi pada hipotesis pertama sebesar $67,2 \%$. Maka dapat disimpulkan bahwa variabel kemampuan berpikir kritis aspek menganalisis siswa kelas $\mathrm{V}$ SDN memberikan sumbangan sebesar $67,2 \%$ terhadap hasil belajar IPA dan sisahnya dari faktor lain.

Data tersebut dapat dikatakan bahwa semakin tinggi kemampuan berpikir kritis aspek menganalisis siswa maka semakin tinggi juga hasil belajar IPA siswa tersebut dan sebaliknya. Penelitian ini sesuai dengan penelitian yang telah telah dilakukan Husnah (2017) menunjukkan kemampuan berpikir kritis siswa memiliki hubungan yang signifikan terhadap hasil belajar fisika siswa SMA dengan nilai R square 0,827 atau 82,7\%.

Analisis hipotesis kedua menggunakan uji korelasi sederhana yaitu nilai signifikansi (2 -tailed) $0,000<0,05$ berarti $\mathrm{H}_{0}$ ditolak, sehingga ada hubungan positif antara berpikir kritis aspek menarik kesimpulan dan hasil belajar IPA. Sedangkan koefisien korelasi $r$ hitung $=0,816$, sedangkan $r$ tabel $(d f=281)$ yaitu 0,116 . Maka nilai $r$ hitung $(0,816)>r$ tabel $(0,116)$ yang berarti memiliki hubungan kuat antara kemampuan berpikir kritis menarik kesimpulan dan hasil belajar IPA siswa kelas V SDN se-Kecamatan Klirong tahun ajaran 2020/2021. Sedangkan, nilai koefisien determinasi hipotesis kedua sebesar $66,5 \%$. Maka dapat disimpulkan bahwa variabel kemampuan berpikir kritis aspek menarik kesimpulan siswa kelas $V$ SDN memberikan sumbangan sebesar $66,5 \%$ terhadap hasil belajar IPA dan sisahnya dari faktor lain.

Data tersebut dapat dikatakan bahwa semakin tinggi kemampuan berpikir kritis aspek menarik kesimpulan siswa maka semakin tinggi juga hasil belajar IPA siswa tersebut dan sebaliknya. Penelitian ini sesuai dengan penelitian yang telah telah dilakukan Ildayanti (2017) menunjukkan kemampuan berpikir kritis siswa memiliki hubungan yang signifikan terhadap hasil belajar Biologi siswa kelas XI IPA SMA Negeri di Kabupaten Pinrang dengan nilai R 0,909 (hubungan sangat kuat) dan nilai koefisien determinasi $\left(R^{2}\right)$ sebesar $82,7 \%$.

Analisis hipotesis ketiga menggunakan uji korelasi berganda yaitu nilai signifikansi (2 -tailed) $0,000<0,05$ berarti $\mathrm{H}_{0}$ ditolak, sehingga ada hubungan positif antara berpikir 
kritis aspek menganalisis dan menarik kesimpulan dengan hasil belajar IPA siswa.Sedangkan koefisien korelas $r$ hitung $(0,885)>r$ tabel $(0,116)$ yang berarti memiliki hubungan kuat antara kemampuan berpikir kritis aspek menganalisis dan menarik kesimpulan dan hasil belajar IPA siswa kelas V SDN se-Kecamatan Klirong tahun ajaran 2020/2021. Sedangkan nilai koefisien determinasi pada hepotisis ketiga sebesar $78,3 \%$. Maka dapat disimpulkan bahwa variabel kemampuan berpikir kritis aspek menganalisis dan menarik kesimpulan siswa kelas $\mathrm{V}$ SDN memberikan sumbangan sebesar $78,3 \%$ terhadap hasil belajar IPA dan sisahnya dari faktor lain.

Data tersebut dapat dikatakan bahwa semakin tinggi kemampuan berpikir kritis aspek menganalisis dan menarik kesimpulan siswa maka semakin tinggi juga hasil belajar IPA siswa tersebut dan sebaliknya penelitian ini sesuai dengan penelitian yang telah telah dilakukan Yuono (2019) menunjukkan kemampuan berpikir kritis siswa memiliki hubungan yang signifikan terhadap hasil belajar Bahasa Indonesia siswa kelas $V$ SDN 2 Mentro Utara dengan nilai R 0,974 (hubungan sangat kuat), nilai koefisien determinasi $\left(R^{2}\right)$ sebesar 0,949 .

\section{SIMPULAN}

Berdasarkan hasil penelitian dan pembahasan dapat disimpulkan: (1) kemampuan berpikir kritis aspek menganalisis berkorelasi positif terhadap hasil belajar IPA, dengan nilai koefisien korelasi 0,820 . Maka tingkat korelasi sangat kuat yaitu semakin tinggi kemampuan berpikir kritis aspek menganalisis siswa maka hasil belajar yang diperoleh semakin tinggi; (2) kemampuan berpikir aspek kritis menarik kesimpulan berkorelasi positif terhadap hasil belajar IPA, dengan nilai koefisien korelasi 0,816 . Maka tingkat korelasi sangat kuat yaitu semakin tinggi kemampuan berpikir kritis aspek menarik kesimpulan siswa maka hasil belajar yang diperoleh semakin tinggi; dan (3) kemampuan berpikir kritis aspek menganalisis dan menarik kesimpulan berkorelasi positif terhadap hasil belajar IPA dengan nilai koefisien korelasi 0,885. Maka tingkat korelasi sangat kuat yaitu semakin tinggi kemampuan berpikir kritis aspek menganalisis dan menarik kesimpulan siswa maka hasil belajar yang diperoleh semakin tinggi.

Implikasi penelitian ini secara teoretis yaitu Penelitian ini menunjukkan bahwa kemampuan berpikir kritis merupakan proses pengalaman dalam pembelajaran yang diperoleh dari hasil mengamati, menganalisis, dan menarik kesimpulan yang dapat dikembangkan. Implikasi secara praktis penelitian ini bagi guru sebagai evaluasi dalam proses pembelajaran dan memberdayakan kemampuan berpikir kritis dengan menggunakan metode pembelajaran berabsis proyek atau praktikum serta membiasakan membaca sebelum pembelajaran. Sekolah juga mendukung dengan membuat kebijakan, menyediakan sarana dan prasarana untuk mendukung kemampuan berpikir kritis di lingkungan sekolah.

\section{DAFTAR PUSTAKA}

Facione, P.A. (2011). Critical thinking: What it is and why it counts. Insight assessment, 2007(1), 1-23.

Huda, M.M \& Rahman, L. (2020). Hubungan Keterampilan Berpikir Kritis dengan Hasil Belajar Siswa Sekolah Dasar. Jurnal Pendidikan Anak dan Karakter, 2(2), 4247.

Husnah, M. (2017). Hubungan Tingkat Berpikir Kritis Terhadap Hasil Belajar Fisika Siswa dengan Menerapkan Model Pembelajaran Problem Based Learning. PASCAL (Journal of Physics and Science Learning), 1(2), 10-17.

Ildayanti. (2017). Hubungan Kemampuan Berpikir Kritis dan Kesadaran Metakognitif dengan Hasil Belajar Biologi Siswa Kelas XI IPA SMA Negeri di Kabupaten Pinrang. Tesis dipublikasi, Program Sarjana Universitas Ngeri Makasar. 
Makhrus, M., dkk. (2018). Identifikasi Kesiapan LKPD Guru Terhadap Keterampilan Abad 21 Pada Pembelajaran IPA SMP. Jurnal IImiah Profesi Pendidikan, 3(2), 124-128.

Nugraha, A. J., Suyitno, H., \& Susilaningsih, E. (2017). Analisis Kemampuan Berpikir Kritis Ditinjau dari Keterampilan Proses Sains dan Motivasi Belajar melalui Model PBL. Journal of Primary Education, 6 (1), 35 - 43.

Peraturan Menteri Pendidikan dan Kebudayaan Republik Indonesia Nomor 64 Kementerian Pendidikan dan Kebudayaan (2013). Standar Isi Pendidikan Dasar Dan Menengah. Jakarta: Kementerian Pendidikan dan Kebudayaan

Prameswari, S. W., Suharno, S., \& Sarwanto, S. (2018). Inculcate Critical Thinking Skills in Primary Schools. In Social, Humanities, and Educational Studies (SHEs): Conference Series, 1 (1).

Pratiwi, J.A., Mirza, A., \& Nursangaji, A. (2015). Kemampuan Berpikir Kritis Aspek Analysis Siswa di Sekolah Menengah Atas. Jurnal Pendidikan dan Pembelajaran Khatulistiwa, 5(12).

Tohir, M. (2019). Hasil PISA Indonesia Tahun 2018 Turun Dibanding Tahun 2015. Diperoleh 25 Oktober 2020, dari https://doi.org/10.31219/osf.io/pcjvx

Yuono, H. (2019). Hubungan Minat Baca dan Kemampuan Berpikir Kritis dengan Hasil Belajar Peserta Didik Pada Muatan Bahasa Indonesia. Jurnal IImiah Pendidikan Guru Sekolah Dasar, 3(2), 181-200. 